\title{
HÁBITOS ALIMENTARES E CÂNCER DIGESTIVO
}

Os hábitos alimentares associados ao aparecimento de doenças têm sido muito estudados e sua influência já foi comprovada na gênese de diversos distúrbios, principalmente cardiovasculares. Com relação ao câncer, existe muita especulação da imprensa leiga sobre a influência dos alimentos quanto à gênese e à cura dessa doença. Mesmo na literatura médica, notamos trabalhos conflitantes sobre o assunto, levando a própria classe médica a uma dificuldade de se posicionar sobre o tema. Esse desconhecimento da influência dos alimentos na gênese do câncer leva principalmente à dificuldade de orientação do paciente quanto à prevenção das neoplasias.

Uma das áreas que mais poderia se beneficiar com esse conhecimento seria a gastroenterologia, tanto pela freqüência das neoplasias digestivas quanto pela sua gravidade. Alguns centros avançados já conseguem orientar seus pacientes sobre os hábitos alimentares e a prevenção do câncer digestivo, principalmente em países do Oriente como o Japão. Mas esse conhecimento ainda está longe do médico clínico ou de centros especializados menores que ainda não fazem a orientação alimentar da população visando a prevenção do câncer digestivo, principalmente em áreas de maior risco dessas doenças. Em estudos importantes já realizados em diversos países onde as neoplasias digestivas têm grande prevalência, como China e Japão, já ficou claramente demonstrada a influência de alimentos defumados ou conservados pelo sal na origem do câncer de estômago, por exemplo. Também nesses países foi demonstrado que o consumo regular de frutas, legumes e verduras frescas tem influência relevante na prevenção do câncer de estômago e colorretal.

Em recente estudo populacional realizado em nove países europeus e com quase 500.000 pessoas, constatou-se que o hábito de comer carne vermelha diariamente aumentou signi- ficativamente $\mathrm{O}$ aparecimento de câncer colorretal quando comparado com uma população que ingeria carne vermelha apenas uma vez por semana. A substituição da carne vermelha por pescados mostrou-se benéfica na diminuição das taxas de câncer do intestino grosso. Dados do Inca (Instituto Nacional de Câncer) demonstram uma grande diferença nas taxas de câncer colônico entre o Amapá e o Rio Grande do Sul, onde este último tem quase 20 vezes mais casos desse tipo de câncer por 100.000 habitantes, fator atribuído ao grande consumo de carne bovina no estado sulista. O hábito de fumar e ingerir bebidas alcoólicas em grande quantidade tem influência na gênese do câncer digestivo, principalmente no que se refere ao câncer de esôfago, e parece haver um benefício das frutas e legumes frescos na diminuição dessa neoplasia. Por muito tempo acreditou-se também que o consumo exagerado de café tinha influência no aparecimento do câncer de pâncreas, mas nenhum trabalho de vulto confirmou esta hipótese.

Alguns autores acreditam que a ingestão de alimentos com pouca gordura e vegetais diariamente evitam o aparecimento de câncer não pelas substâncias que contêm, mas sim por essas pessoas, com esses hábitos alimentares, serem mais magras e mais ativas fisicamente e, portanto, apresentarem menos doenças. Essa parece ser uma boa colocação; no entanto, constatamos que os habitantes do Japão e China, por exemplo, dificilmente são obesos e têm o hábito de caminhar muito e mesmo assim apresentam grandes taxas de câncer digestivo.

Em conclusão, podemos afirmar que, apesar de ser um assunto ainda polêmico e em estudo, há dados suficientes na literatura para recomendarmos a diminuição da ingestão de carne vermelha e o aumento do consumo de peixes, frutas, verduras e legumes frescos na prevenção do câncer digestivo.

Elias JiRJoss Ilias 